\title{
Effect of Alkali Treatment on Interfacial and Mechanical Properties of Kenaf Fibre Reinforced Epoxy Unidirectional Composites
}

\author{
(Kesan Rawatan Alkali kepada Sifat Antara Muka dan Mekanik Komposit Uniarah Serabut Kenaf
} Memperkukuh Epoksi)

\begin{abstract}
ZILONG REN, CHUNHONG WANG*, Qi ZUO, SHERAZ HuSSAIN SidDiQUE YousFANI, NOOR INTAN SAFFINAZ ANUAR, SARANI ZAKARIA \& XIAOLING LIU
\end{abstract}

ABSTRACT

Kenaf fibres demonstrate enormous potential in fibre reinforced composites with the excellent performance and environmental benefits. In this work, kenaf fibres were treated with $\mathrm{NaOH}$ at the concentrations of 1\%, 2\%, and 3\%. Effects of the alkaline treatments on the mechanical properties of fibre and interfacial shear properties (IFSS) of the resulted composites were systematically evaluated. In addition, relationship between tensile strength and surface friction coefficient of kenaffibre was shown. Relationship between tensile strength of fibre and IFSS of composites were explored. They were conducted by correlation analysis method. The results indicated that after NaOH treatment, kenaf fibres has increased in tensile strength, surface roughness, friction coefficient, but decreased in diameter. Tensile properties, flexural properties and water absorption of unidirectional kenaf fibre reinforced epoxy resin composites have improved. IFSS of composite treated at $2 \%$ alkali has increased by $10.34 \%$, compared to composites untreated fibres. Correlation analysis indicated that there was no significant correlation between kenaf fibre tensile strength and IFSS of the composite. On the other hand, there was significant correlation between kenaf fibre surface friction and the IFSS of the composite with the correlation coefficient of 0.905 .

Keywords: Correlation analysis method; interfacial shear strength (IFSS); NaOH; surface friction

ABSTRAK

Serabut kenaf menunjukkan potensi besar dalam pembuatan komposit diperkuat serabut disebabkan ia mempunyai prestasi cemerlang dan kesan positif kepada alam sekitar. Dalam kajian ini, serabut kenaf dirawat dengan natrium hidroksida $(\mathrm{NaOH})$ pada kepekatan 1\%, 2\% dan 3\%. Kesan rawatan alkali terhadap sifat mekanik serabut dan sifat geseran permukaan (IFSS) daripada komposit yang dihasilkan dinilai secara sistematik. Di samping itu, hubungan antara kekuatan tegangan dan koefisien geseran permukaan serabut kenaf telah dinyatakan. Hubungan antara kekuatan tegangan serabut dan IFSS komposit telah diterokai. Analisis dijalankan melalui kaedah analisis korelasi. Keputusan menunjukkan selepas rawatan $\mathrm{NaOH} \mathrm{1 \% ,} \mathrm{serabut} \mathrm{kenaf} \mathrm{meningkat} \mathrm{dalam} \mathrm{kekuatan} \mathrm{tegangan,} \mathrm{kekasaran} \mathrm{permukaan,}$ koefisien geseran dan penurunan diameter. Sifat tegangan, sifat lentur dan penyerapan air komposit resin epoksi diperkuat serabut menunjukkan peningkatan. IFSS komposit dengan serabut yang dirawat dengan $2 \%$ alkali meningkat sebanyak $10.34 \%$, berbanding komposit dengan serabut yang tidak dirawat. Analisis korelasi menunjukkan tiada korelasi yang ketara antara kekuatan tarik serabut kenaf dan IFSS komposit. Sebaliknya, terdapat hubungan yang signifikan antara geseran permukaan serabut kenaf dan IFSS komposit dengan koefisien korelasi sebanyak 0.905.

Kata kunci: Kaedah analisis korelasi; kekuatan geseran permukaan (IFSS); NaOH; permukaan geseran

\section{INTRODUCTION}

Recently, green composites with natural fibres as reinforcing materials have attracted more attention in various application. This interest was contributed by the shortage in resources and prominent environmental protection issue of synthetic materials, as well as the environmental friendly of natural fibres. Plant fibres also have brighter prospects in industrial applications due to their excellent performances of light weight, high specific strength and stiffness, renewable and biodegradable (Reza et al. 2013; Sathishkumar et al. 2012).
Among the natural fibres available, kenaf bast fibre possess excellent properties such as tough texture, long fibre bundle, relatively fair colour, good tensile strength and wear resistant. At the same time, kenaf fibre is sold at moderate price of USD550-650/ton compare to ramie fibre that is sold at USD1450-1600/ton and flax fibre at USD5500-9500/ton (He 2013). Hence, more attention has been paid on the kenaf fibre due to its excellent performance and moderate price.

The main chemical compositions of kenaf fibres such as cellulose, hemicellulose, lignin, and extractive 
contain a great number of hydroxyl groups and strong hydrogen bonds which would contribute to strong fibre hydrophilicity and polarity. Interfacial compatibility between the hydrophilic kenaf fibre and hydrophobic resin is poor. Therefore, proper treatment for kenaf fibre is necessary to improve the interfacial adhesion before the fabrication of composites to improve the mechanical properties (Reza Mahjouba et al. 2014; Tim Huber et al. 2012).

Alkali treatment is one of the most effective methods for surface modification of natural fibres and a legion of researchers has focused their attention on improving the mechanical properties of natural fibres composites by this treatment (Rawal et al. 2014). Ming Cai et al. (2016) reported that after $5 \% \mathrm{NaOH}$ treatment for $2 \mathrm{~h}$ on abaca fibres showed increased in crystallinity, tensile strength and Young's modulus compared to untreated fibres, and also improved in interfacial shear strength of abaca fibre reinforced epoxy composites. Fiore et al. (2015) reported that the optimum $\mathrm{NaOH}$ concentration was achieved at $6 \%$, to improve the fibre-matrix compatibility, and then improved the mechanical properties of composites. Gomes et al. (2007) reported that a $10 \%$ concentrated alkali treatment of curaua fibres increased the toughness and strength compared to untreated curaua fibres and subsequently improved the mechanical properties of curaua/PLA composites. Saha et al. (2010) reported that after dipping jute fibres in a $0.5 \%$ alkali solution, the tensile strength of the fibres increased by $65 \%$. According to the study by Wang et al. (2016), the bamboo fibre surface polarity was reduced by $63.64 \%$ after $1 \%$ alkali treatment and with $2 \%$ alkali treatment, the adhesion work between bamboo fibre and PP resin increased by $67.18 \%$. The bamboo fibre/PP composite's shear property also increased by $23.29 \%$, compared with the untreated fibre (Wang \& Liu 2015; Wang et al. 2016).

Figure 1(a) shows the schematic diagram of alkaline treatment on natural fibre. The alkali dissolvable extractive and chemical constituent of fibre is extracted during the alkali treatment. Alkali treatment disturbs the crystalline region in cellulose which allow fibre to swell. After the alkaline treatment, natural bending cellulose would convert into more straight and parallel with higher thermodynamicstability (Mwaikambo et al. 2002). The corrosiveness of alkali can remove the hemicellulose, lignin, wax and other impurities on the fibre surface which loosen and soften the fibre (Liao et al. 2011). Furthermore, alkaline treatment increases the surface roughness of natural fibre and strengthens the mechanical interlocking between natural fibre and resin (Mwaikambo et al. 2002). Peng et al. (2011) reported that the content of cellulose on the fibre surface was reduced due to the degradation. The cellulose on the surface after alkaline treatment are more exposed since they are located in the secondary layer of the cell wall, S1, S2 and S3. The amount of cellulose exposed on the fibre surface are increased, which can increase the number of reactive sites, contribute to the improvement of the composite properties (Peng et al. 2011). The chemical reaction of alkali treatment is shown in Figure 1(b).

This study primarily aimed to improve the mechanical properties and interfacial bonding property by alkali treatment. The effect of alkali treatment on diameter, tensile strength, surface friction, and microstructure of kenaf fibre were studied. Unidirectional continuous kenaf fibre reinforced epoxy resin composites were prepared to show the effect of the alkali treatment on the mechanical properties, water absorption and interfacial shear strength (IFSS) of the composites. By using Correlation Analysis Method, correlation analysis between kenaf fibre tensile strength and the interfacial shear strength (IFSS) of the composite was carried out. Correlation analysis between kenaf fibre surface friction and the interfacial shear strength (IFSS) of the composite was also conducted. These were considered to be conducive to provide the basis for the prediction of interface shear strength (IFSS) of the composites.

\section{MATERIALS AND METHODS}

\section{MATERIALS}

Kenaf fibres used in this study was supplied by the Timber Industry Board Malaysia (MTIB), which were treated by water retting method in a natural pond. Kenaf fibres were completely immersed in an aqueous $\mathrm{NaOH}$ solution (concentrations: 1, 2 and 3 wt. \%, respectively, ratio of kenaf fibre and $\mathrm{NaOH}$ solution was 1:20) for 40 min at $100^{\circ} \mathrm{C}$ to ensure good penetration of the alkali solutions

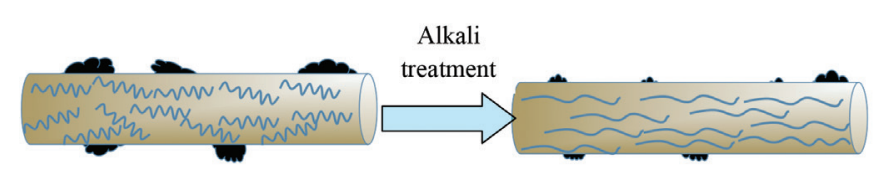

(a)

$\mathrm{Cell}-\mathrm{OH}+\mathrm{NaOH} \rightarrow \mathrm{Ce} l \mathrm{l}-\mathrm{O}^{-} \mathrm{Na}^{+}+\mathrm{H}_{2} \mathrm{O}+$ surface impurities

(b)

FIGURE 1. (a) Principle of alkali treatment of natural fibre (b) Chemical reaction formula for alkali treatment of natural fibre 
into the fibre bundles. Then, fibres were washed several times using fresh tap water until neutral $\mathrm{pH}$ to ensure complete removal of the $\mathrm{NaOH}$. Finally, the fibres were dried in an oven at $80^{\circ} \mathrm{C}$ for $2 \mathrm{~h}$ and the moisture content of dried fibre was lowered than $0.1 \%$. The epoxy resin (Type YJ-80) was supplied by HuiBai New Material and Technology Co Ltd (Shanghai, China) used as matrix to fabricate the composites.

\section{FABRICATION OF THE COMPOSITES}

The unidirectional continuous kenaf fibre reinforced epoxy resin composites were fabricated with the kenaf fibre volume fraction of $70 \%$. Firstly, the alkali treated long kenaf fibre were cut to $200 \mathrm{~mm}$, then combed to make them parallel. Later the kenaf fibres were stitched to form unidirectional fibrofelt and dried in an oven at $80^{\circ} \mathrm{C}$ for $1 \mathrm{~h}$. The fibrofelt were coated evenly with resin by hand lay-up. Fibrofelts were placed in the room temperature $\left(22^{\circ} \mathrm{C}\right)$ for $24 \mathrm{~h}$ to allow sufficient acetone volatilization. Then, the fibrofelts were laminated and placed in the mold and pressed for $3 \mathrm{~min}$ with the pressure of $4 \mathrm{MPa}$ at $135^{\circ} \mathrm{C}$ with 1 min taken to release pressure. The above procedure was repeated twice. Finally, samples were pressed for $2 \mathrm{~h}$ with the pressure of $10 \mathrm{MPa}$ at $135^{\circ} \mathrm{C}$.

\section{PROPERTY TESTING DIAMETER TESTING OF KENAF FIBRE}

Diameters of kenaf fibre bundle were measured by using a VHX-1000 digital microscope (Keyence Corporation, Japan) according to standard SN/T 2672-2010.

\section{TENSILE PROPERTY TESTING OF KENAF FIBRES}

Tensile properties of kenaf fibre bundle were tested in accordance to ASTM D1294-05 standard. The test was conducted on Model 3369 Instron electronic universal testing machine (Instron, USA). Each bundle of kenaf fibres were prepared at $25 \mathrm{mg}$ of $50 \mathrm{~mm}$ length fibres. The gauge length was kept for $25.4 \mathrm{~mm}$ with testing speed at $250 \mathrm{~mm} / \mathrm{min}$. The tests were run with 20 replicates and average of tensile strength; tensile modulus and elongation at failure/break were obtained. The test was carried out at the conditions of $20 \pm 1 \%$ and $65 \pm 2 \%$ relative humidity.

\section{FRICTION COEFFICIENT TESTING OF KENAF FIBRES}

Friction coefficient of kenaf single fibres were measured by using the Y151 Friction Coefficient Testing Instrument (Changzhou DePu Textile Technology Co., Ltd. China). The speed of friction roller was 30 r.p.m., and $500 \mathrm{mg}$ fibre clip was adopted. Twenty samples were tested and average of the friction coefficient was obtained. The test was carried out at the conditions of $20 \pm 1 \%$ and $65 \pm 2 \%$ relative humidity. The calculation is shown as follows:

$$
\mu=0.733 \times\left[\lg \left(m_{1}\right)-\lg \left(m_{1}-m_{2}\right)\right]
$$

where $\mu$ is the friction coefficient of kenaf fibre; $m_{1}$ is the weight of fibre clip; and $m_{2}$ is the reading of the balance.

\section{THE MICROSTRUCTURE OBSERVATION OF KENAF FIBRES AND COMPOSITES}

The morphologies of kenaf fibres and composites were examined by using a TM3030 scanning electron microscope (JEOL Ltd. Japan). The samples were coated with Au before testing to minimize the static electricity under the electron beam.

\section{MECHANICAL PROPERTY TESTING OF COMPOSITES}

The mechanical property tests were performed by using a Model 3369 Instron electronic universal testing machine (Instron, USA) under the conditions of $20 \%$ and $65 \%$ relative humidity.

The tensile properties were measured in accordance with ASTM D638-2003 standard. The dimension of the specimen, gauge length and crosshead displacement were set at $160 \mathrm{~mm} \times 12.5 \mathrm{~mm} \times 3 \mathrm{~mm}$, gauge $90 \mathrm{mmt}$ and 2 $\mathrm{mm} / \mathrm{min}$, respectively.

Samples were subjected to a three-point flexural test to determine the flexural properties. The tests were conducted following the ASTM 790-30 standard at a testing speed of $2 \mathrm{~mm} / \mathrm{min}$, dimension of specimen of $60 \mathrm{~mm} \times 12.5 \mathrm{~mm}$ $\times 3 \mathrm{~mm}$ and fulcrum span of $48 \mathrm{~mm}$.

\section{WATER ABSORPTION TESTING OF THE COMPOSITES}

The water absorption behaviors of composites were measured according to ASTM D570-2005 standard. For each fibre group, five composite samples with dimension of $76.2 \mathrm{~mm} \times 25.4 \mathrm{~mm} \times 3 \mathrm{~mm}$ were prepared. Specimens were dried in the desiccator at $105^{\circ} \mathrm{C}$ for $24 \mathrm{~h}$, then cooled down to the room temperature. After weight measurement, they were immersed in distilled water for $72 \mathrm{~h}$ at room temperature. Water on the surface was wiped dry and specimens were weighed again. The water absorption of composites was calculated by (2):

$$
\text { Water absorption } / \%=\frac{W_{1}-W_{0}}{W_{0}} \times 100 \%
$$

where $W_{0}$ is the weight after drying of composites; and $W_{1}$ is the weight after water absorption of composites.

\section{INTERFACIAL SHEAR STRENGTH TESTING OF COMPOSITES}

The interfacial shear strength test was performed by using a Model 3369 Instron electronic universal testing machine (Instron, USA) under room conditions of $20 \%$ and $65 \%$ relative humidity. The test was conducted in accordance to JC/T 773-2010 standard. The testing was set at speed of $1 \mathrm{~mm} / \mathrm{min}$, dimension of the specimen of $30 \mathrm{~mm} \times 15$ $\mathrm{mm} \times 3 \mathrm{~mm}$ and fulcrum span of $16 \mathrm{~mm}$. 


\section{RESULT AND DISCUSSION}

\section{EFFECT OF ALKALI TREATMENT ON THE PROPERTIES OF KENAF FIBRE DIAMETER OF ALKALI- TREATED KENAF FIBRES}

Diameters of untreated and alkali-treated kenaf fibres are given in Figure 2(a). It shows that after $1 \%$ of $\mathrm{NaOH}$ treatment, the diameter of fibres reduced by $17.11 \%$. When the $\mathrm{NaOH}$ concentration increased up to $3 \%$, the weight of fibre has reduced. This is due to the removing of pectin, wax and other impurities from the surface of fibre. The results showed that fibre diameters increased with the alkali adding from $1 \%$ to $2 \%$ but decreased when the concentration of alkali was $3 \%$. As the alkali concentration increased from $1 \%$ to $2 \%$, they gradually entered into the interior of kenaf fibre, which increased the contact zone among the amorphous, and destroyed the hydrogen bonds between celluloses. This swelling effect of fibre has increased the diameter of fibre. However, when the $\mathrm{NaOH}$ concentration was $3 \%$, no significant improvement on the fibre diameter. This is due to the swelling effect of the fibre has reached the optimum level related to the hydrogen bond breakage (Wang et al. 2017).

\section{TENSILE PROPERTIES OF ALKALI-TREATED KENAF FIBRES}

Tensile properties untreated and treated fibres are shown in Figure 2(b). It shows that the tensile strength for $1 \%$ treated fibre increased by $11.87 \%$ compared to the untreated kenaf. The treatment removed a certain amount of lignin, wax and pectin that covering the external surface of fibre cell wall and depolymerized the cellulose which resulting in parallel arrangement of cellulose (Misra et al. 2011). The cellulose parallel arrangement has improved the tensile strength of kenaf fibre. However, the tensile strength of kenaf fibre was reduced to $326.23 \mathrm{MPa}$ after 3 wt. $\% \mathrm{NaOH}$ treatment which was $8.24 \%$ lowered than the untreated fibre. This was regarded to excessive amounts of $\mathrm{NaOH}$ that damaged the structure of cellulose in the fibres and degraded the macromolecular chains of cellulose into short molecular chains and microcrystalline structures. Since the cellulose (kenaf fibre) is the load-bearing components, their degradation affect the tensile strength of kenaf fibre accordingly (Xue et al. 2007).

\section{FRICTION COEFFICIENT OF ALKALI-TREATED KENAF FIBRES}

As shown in Figure 2(c), the surface friction coefficient of kenaf fibre increased with the increase of $\mathrm{NaOH}$ concentration. Alkali treatment has removed a certain amount of extractive like pectin, impurities, and chemical constituent such as hemicellulose, lignin on the surface of kenaf fibre and the area of alkaline penetration. The treatment has roughened the surface of kenaf fibre. At the same time, $\mathrm{NaOH}$ reacted with the hydroxyl groups in kenaf fibre as shown in (3), which destroyed the hydrogen bonds in the cellulose chains, reduced the fibre density, and loosen the kenaf fibres. This may increase the effective contact area between the fibre and the matrix subsequently enhanced the interfacial bonding strength. These may be beneficial to improve the friction coefficient of the kenaf fibre.

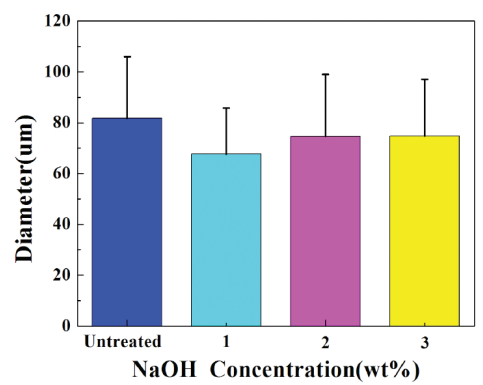

(a)

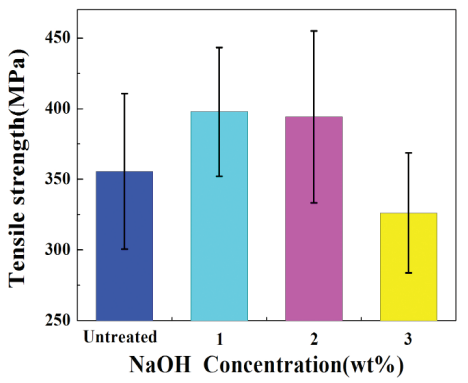

(b)

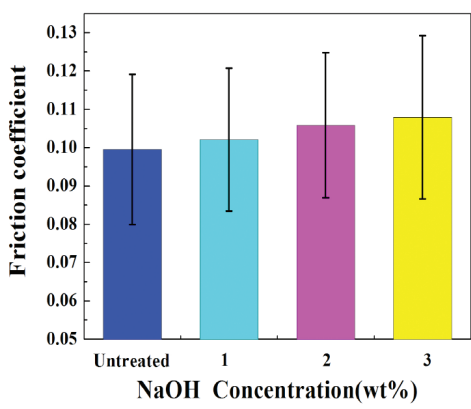

(c)

FIGURE 2. Effect of alkali treatment on (a) The kenaf fibre diameter (b) Tensile strength (c) Friction coefficient and (d) shear strength 


$$
\text { Fiber }-\mathrm{OH}+\mathrm{NaOH} \rightarrow \text { Fiber }-\mathrm{O}^{-} \mathrm{Na}^{+}+\mathrm{H}_{2} \mathrm{O}
$$

\section{SURFACE MORPHOLOGIES OF ALKALI-TREATED KENAF FIBRES}

Figure 3 shows the surface morphology of alkali treated and untreated kenaf fibres. The untreated fibre surface was covered with extractives which were likely pectin and other substances together with lignin mostly located in the middle lamella. The cell wall structure consists of three major chemical constituents that are lignin, hemicellulose, and cellulose. The alkaline treatment would have contributed to rough surface of the fibre (Figure 3(b)3(d)) which may cause bigger friction coefficient.

In the case of $1 \mathrm{wt} . \%$ alkali-treated fibre, the amount of impurities on the fibre surface was reduced (Figure 3(b)). Grooves between single fibres in the bundles were clearly visible and expected to aid adhesion with composite matrices. In the cases of the 2 and $3 \mathrm{wt}$. \% alkali-treatments, excess alkali may corrode and roughen the surface of the fibre, as shown in Figure 3(c) and 3(d) (John et al. 2008; Li et al. 2007; Moyeenuddin et al. 2011; Mwaikambo et al. 2007; Nam et al. 2011; Ray et al. 2001; Scarponi et al. 2012; Wang et al. 2008).

Generally, the alkali treatment with 1 wt. \% concentration mainly has three effects on the kenaf fibres. It could partially remove the amorphous hemicellulose results in rearrangement of cellulose chains and increased of the kenaf fibre strength (Ma et al. 2002). It could improve the surface roughness of the fibre, which was helpful to improve the mechanic interlocking between fibres and resin. It could reduce the surface polarity (Wang et al.
2016), removed the pectin and lignin which increased the cellulose exposure on kenaf fibre surface, thus increased the number of possible reaction sites and contact areas between kenaf fibres and resin (Rokbi 2011; Valadez 1999).

EFFECTS OF ALKALI TREATMENT ON THE PHYSICAL AND MECHANICAL PROPERTIES OF KENAF FIBRE REINFORCED EPOXY RESIN COMPOSITES MECHANICAL PROPERTIES OF KENAF FIBRE REINFORCED EPOXY RESIN COMPOSITES

The tensile and flexural properties of the alkali-treated and untreated composites are presented in Figure 4. As shown in the figure, both tensile and flexural properties were improved when $1 \mathrm{wt}$. \% alkali concentration was used to treat the fibres and reduced as the alkali concentration increased.

In the case of the $1 \mathrm{wt} . \%$ alkali concentration, the tensile strength, tensile modulus, flexural strength, and flexural modulus of the composites were $16.95 \%, 17.42 \%$, $10.66 \%$, and $14.80 \%$ greater than that of the untreated fibres, respectively.

Untreated kenaf fibres were covered with lignin, pectin, wax, and natural oils, which could prevent the combination between fibre and resin. Treatment with $\mathrm{NaOH}$ could remove certain extractives, rearrange cellulose chains, increased fibre strength and produced fibres with rough surface topography (Mwaikambo et al. 2002). In addition, alkali treatment could reduce the surface polarity (Wang et al. 2016) and exposed cellulose thus may increase the number of possible reaction sites and contact areas between kenaf fibres and resin. Therefore, alkali treatment could increase the compatibility of nonpolar polymer interface with natural fibres (El-Shekeil et al.

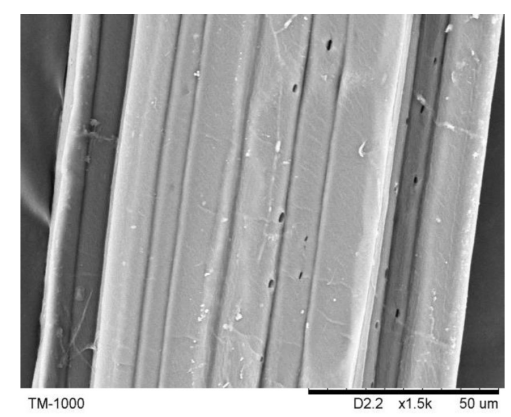

(a) untreated

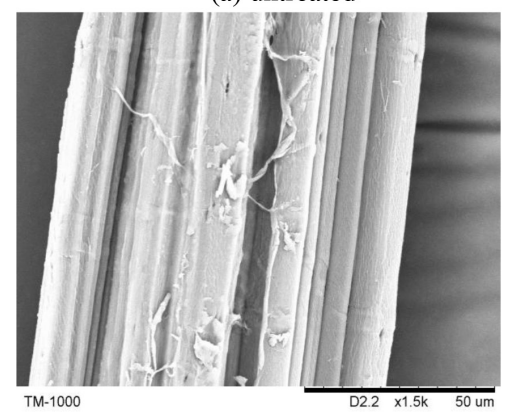

(c) 2 wt. \% alkali treated

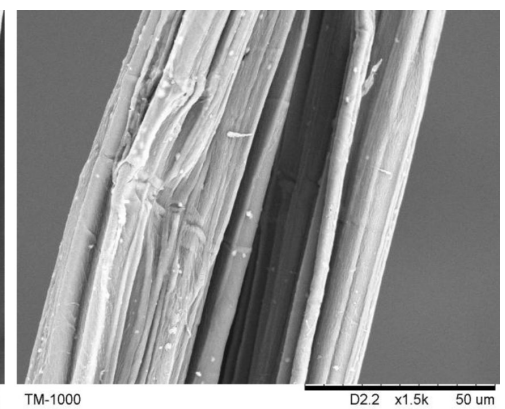

(b) 1 wt. \% alkali treated



(d) 3 wt. \% alkali treated

FIGURE 3. The SEM of kenaf fibre after alkali treatments (a) untreated, (b) 1 wt. $\%$ alkali treated, (c) 2 wt. $\%$ alkali treated and (d) 3 wt. \% alkali treated 


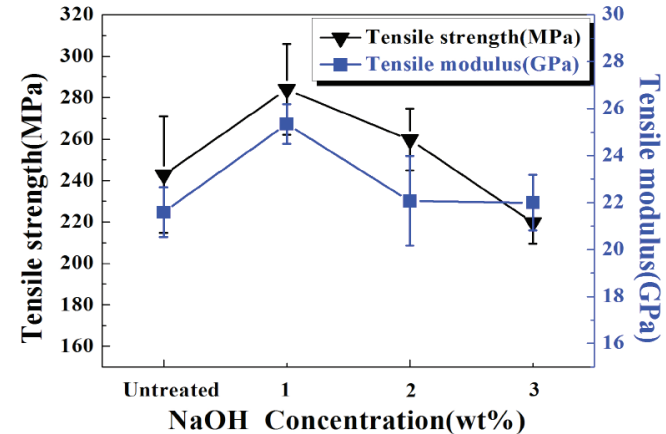

(a) Tensile properties

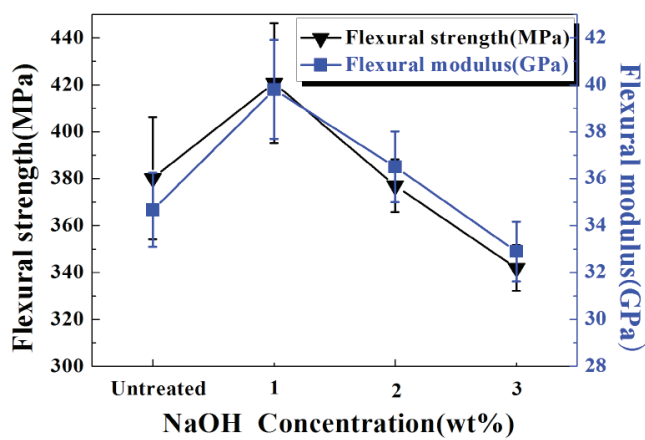

(b) Flexural properties

FIGURE 4. Mechanical properties of kenaf fibre reinforced epoxy resin composites

(a) Tensile properties and (b) Flexural properties

2002). However, excessive $\mathrm{NaOH}$ could change the fine structure of the native cellulose I to cellulose II, and caused the loss of the mechanical properties of the fibre bundle.

\section{WATER ABSORPTION OF KENAF FIBRE REINFORCED EPOXY RESIN COMPOSITES}

Figure 5 illustrates the effects of the alkali concentration on the water absorption properties of the resulted composites. After the alkali treatment, water absorptions of composites were decreased for all the three cases. The water absorptions showed an increase with the increased of alkali concentration. When the $\mathrm{NaOH}$ concentration was $1 \mathrm{wt} \%$, the water absorption of the composites reached to the lowest of $31.09 \%$, which was $13.26 \%$ lower than untreated kenaf fibre composite.

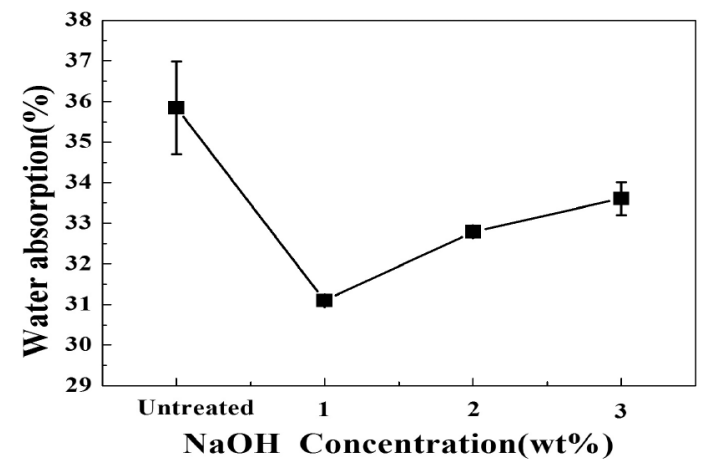

FIGURE 5. Water absorption of kenaf fibre reinforced epoxy resin composites

Interface between fibre and resin was an important factor that affect the water absorption. Specific surface area of fibre and contact area between fibre and resin increased after alkali treatment. These would improve the interfacial bonding between fibre and matrix and reduced voids in the composites. This would cause water molecules difficult to permeate into the material, resulting a decreased in water absorption. With the increased of $\mathrm{NaOH}$ concentration, excess alkali would damage interface between fibre and resin, which made water molecules easier to penetrate into the material, resulting in an increased of water absorption.

\section{EFFECTS OF ALKALI TREATMENT ON THE INTERFACIAL BONDING PROPERTIES OF KENAF FIBRE REINFORCED EPOXY RESIN COMPOSITES}

The unidirectional continuous kenaf fibre composites were prepared by stitching and molding processes. The orientation and arrangement of kenaf fibres in the composites was in same direction. This means that the kenaf fibres were fabricated in one direction to make unidirectional kenaf fibre reinforced composites. The interfacial shear strength of the composites could characterize the bonding properties between the fibre and the resin (Reza et al. 2014).

\section{MICROSCOPIC STRUCTURE OF KENAF FIBRE REINFORCED EPOXY RESIN COMPOSITES}

Figure 6 illustrates cross-section of composites by using alkali- treated and untreated kenaf fibres, respectively. The SEM images show that the bonding of epoxy with fibres differed considerably depending on fibre treatment. Visible crevices could be seen between fibre and epoxy matrix. Voids were also observed for the untreated fibres composite (Figure 6(a)) suggesting poor interfacial adhesion between fibres and resin. These were caused by incompatibility between hydrophilic fibres and hydrophobic epoxy matrix. After alkali treatment, there were almost no gaps between fibres and resin, and cross-section of composite was relatively neat, indicating kenaf fibres were well bonded with epoxy resin, as showed in Figure 6(b) (Wang et al. 2017).

\section{INTERFACIAL SHEAR STRENGTH (IFSS) OF KENAF FIBRE REINFORCED EPOXY RESIN COMPOSITES}

Figure 7 shows the interfacial shear strength of composites. The average interfacial shear strength was $25.62 \mathrm{MPa}$ for 2 wt. \% alkali treated composites, which was $10.34 \%$ greater than untreated fibres composites.

There were two possible reasons for the increase in the interfacial shear strength. Firstly, the fibre surface 


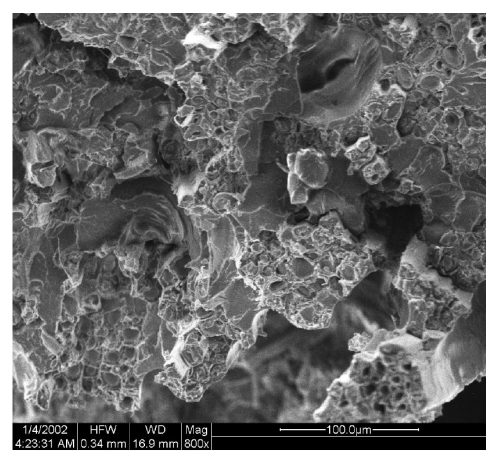

(a) Untreated fibre

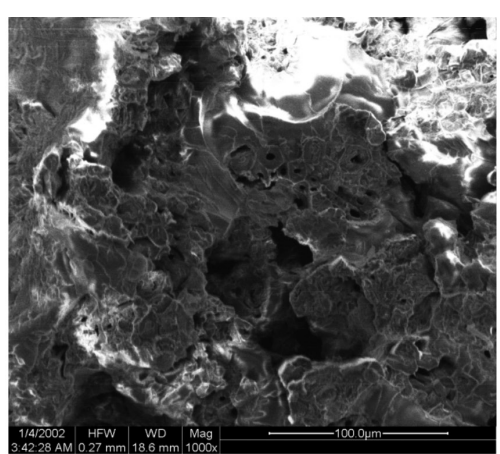

(b) 1 wt. \% alkali treated

FIGURE 6 . Section show of the composites by using alkali treated and kenaf fibres (a) original fibre and (b) $1 \mathrm{wt} . \%$ alkali treated

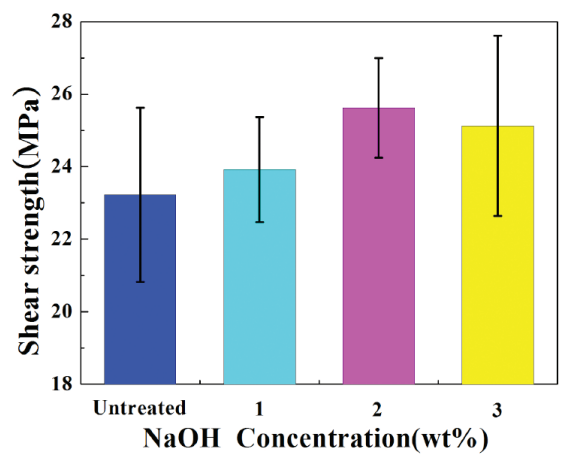

FIGURE 7. The interfacial shear strength of unidirectional continuous kenaf fibre reinforced epoxy resin composites

was cleaner and rougher after alkali treatment, which were helpful to improve the mechanic interlocking between fibres and resin (Figure 6). Alkali treatment can effectively reduce the hydrophilic groups (such as $-\mathrm{OH})$ in kenaf fibre surface, thereby reduced the surface polarity of kenaf fibre, which is conducive to improve the bonding strength between fibre and resin (Li et al. 2007). At 3 wt. \% concentration $\mathrm{NaOH}$, a certain percentage of extractive, lignin and hemi cellulose have been removed and the three-dimensional reticular formation of pectin, lignin, hemicellulose and cellulose was destroyed. More outside shear stress would be shared by the resin instead of the fibre. The negligible improvements in the interfacial shear strength of the composites would be resulted by the reduction of shear strength at $3 \mathrm{wt}$ \% alkali treated fibres.

\section{CORRELATION ANALYSIS BETWEEN THE KENAF FIBRE PROPERTIES AND INTERFACIAL SHEAR STRENGTH (IFSS) OF THE COMPOSITES}

In order to explore the influence of kenaf fibre properties on interfacial shear strength of composites, correlation analysis was carried out between fibre tensile strength and interfacial shear strength, as well as between fibre friction coefficient and interfacial shear strength of the composite, as shown in Table 1(a) and Figure 8(a). There was no significant correlation between kenaf fibre tensile strength and interfacial shear strength, and correlation coefficient $\mathrm{R}^{2}$ was only 0.435 .

The relationship between the friction coefficient of kenaf fibres and interfacial shear strength of composites is shown in Table 1(b) and Figure 8(b), and it showed that a polynomial relationship existed between the two. The interfacial shear strength of composite increased with the
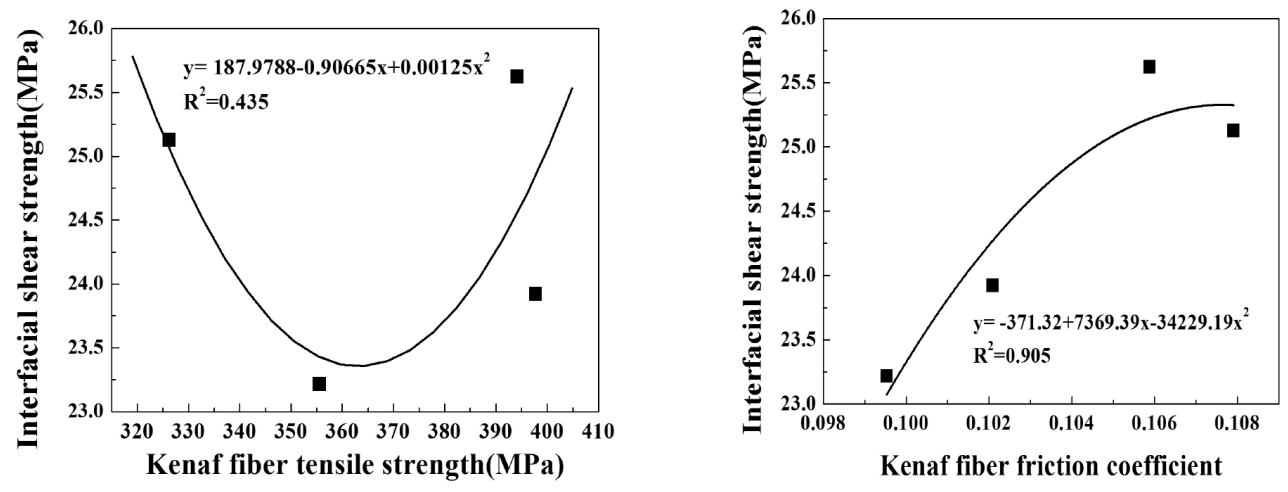

Kenaf fibre tensile strength (b) Kenaf fibre friction coefficient

FIGURE 8. Correlation analysis of kenaf fibre properties and interfacial shear strength of composites (a) Kenaf fibre tensile strength and (b) Kenaf fibre friction coefficient 
TABLE 1 . The model fitted with kenaf fibre properties and interfacial shear strength of composites

\begin{tabular}{cccccc}
\hline Model & Fitting formula & $\mathrm{R}^{2}$ & $\mathrm{~F}$ & $\mathrm{P}$ & Significant \\
\hline $\mathrm{a}$ & $\mathrm{y}=187.9788-0.90665 \times+0.00125 \times^{2}$ & 0.435 & 0.386 & 0.061 & \\
$\mathrm{~b}$ & $\mathrm{y}=-371.32+7369.39 \times-34229.19 \times \times^{2}$ & 0.905 & 10.693 & 0.012 & $*$ \\
\hline
\end{tabular}

a - Correlation analysis of kenaf fibre tensile strength and interfacial shear strength of composites

b - Correlation analysis of kenaf fibre friction coefficient and interfacial shear strength of composites

increase of kenaf fibre friction coefficient. The effect of kenaf fibre friction coefficient on interfacial shear strength was significant with correlation coefficient $\mathrm{R}^{2}$ of 0.905 . $\mathrm{NaOH}$ treatment on kenaf fibre with appropriate alkali concentrations could remove pectin, hemicellulose, lignin, and other impurities in kenaf fibre surface, and roughen the surface of the fibre. These would improve the friction coefficient of the kenaf fibre, increase the effective contact area between fibre and matrix in composites, enhance the interfacial bonding strength, and improve the interfacial shear strength of the composites (Fiore et al. 2015; Ming et al. 2016).

\section{CONCLUSION}

Alkali treatment is a useful chemical treatment for natural fibres used as the reinforcement for the composites. The extractive were removed effectively after the alkali treatment, causing the decreasing of the fibre diameter, increasing the tensile strength, surface roughness and friction coefficient of the fibre. Moreover, the mechanical properties, water absorption and interfacial shear strength (IFSS) of the unidirectional continuous kenaf fibre reinforced epoxy resin composites have improved to some extent with the treatment of the kenaf fibre by the $1 \mathrm{wt}$. $\%$ alkali concentration. Correlation analysis showed that there was little correlation between the kenaf fibre tensile strength and the composite interfacial shear properties (the correlation coefficient $\mathrm{R}^{2}$ was only 0.435 ). However, the effect of surface friction coefficient of kenaf fibre on the interfacial shear strength of composite was obvious with the correlation coefficient $\mathrm{R}^{2}$ of 0.905 .

\section{ACKNOWLEDGEMENTS}

The authors acknowledge the financial support provided by the National Natural Science Foundation of China(11802205), and the research grants of the state key laboratory of automotive safety and energy of Tsinghua University(KF1811).

\section{REFERENCES}

El-Shekeil, Y.A., Sapuan, S.M. \& Khalina, A. 2012. Effect of alkali treatment on mechanical and thermal properties of kenaf fiber-reinforced thermoplastic polyurethane composite. Journal of Thermal Analysis and Calorimetry 109: 14351443.

Fiore, V., Di Bella, G. \& Valenza, A. 2015. The effect of alkaline treatment on mechanical properties of kenaf fibers and their epoxy composites. Composite Part B 68: 14-21.
Gomes, A., Matsuo, T., Goda, K. \& Ohgi, J. 2007. Development and effect of alkali treatment on tensile properties of curaua fiber green composites. Composite Part A 38(8): 1811-1820.

He, S.H.H. 2013. Kenaf/aramid yarn and composite material preparation and properties research. TianJin: Tianjin Polytechnic University.

John, M.J. \& Anandjiwala, R.D. 2008. Recent developments in chemical modification and characterization of natural fiberreinforced composites. Polymer Composite 29(2): 187-207.

Li, X., Tabil, L.G. \& Panigrahi, S. 2007. Chemical treatment of natural fiber for use in natural fiber-reinforced composites: A review. Journal of Polymers and the Environment 15(1): 25-33.

Liao, T.T.,Liu, H. \& Wu,H.W. 2011. Preparation and mechanical properties of discontinuous alkali treated sisal fiber reinforced PLA composites. China Plastics Industry 39(12): 93-97.

Ma, Y.F., Zhang, W., Wang, C. \& Fuxiang, C.H.U. 2002. Progress in interfacial modification methods of natural fiber composites. Materials Review 25(19): 81-84.

Ming, C., Hitoshi, T., Antonio, N. \& Nakagaito. 2016. Effect of alkali treatment on interfacial bonding in abaca fiberreinforced composites. Composites: Part A 90: 589-597.

Misra, S.S., Ahankari, A.K. \& Mohanty, A.D. 2011. Creep and fatigue of natural fiber composites. In Interface Engineering of Natural Fiber Composites for Maximum Performance, edited by Zafeiropoulos, N.E. Cambridge: Woodhead Publishing Limited. pp. 289-340.

Moyeenuddin, A., Sawpan, K.L. \& Pickering, A.F. 2011. Effect of fiber treatments on interfacial shear strength of hemp fiber reinforced polylactide and unsaturated polyester composites. Composites: Part A 49(2): 1189-1196.

Mwaikambo, L.Y. \& Ansell, M.P. 2002. Chemical modification of hemp, sisal, jute, and kapok fibers by alkalization. Journal of Applied Polymer Science 84(12): 2222-2234.

Mwaikambo, L.Y., Tucker, N. \& Clark, A.J. 2007. Mechanical properties of hemp fiber reinforced euphorbia composites. Macromolecular Materials and Engineering 292(9): 9931000.

Nam, T.H., Ogihara, S. \& Tung, N.H. 2011. Effect of alkali treatment on interfacial and mechanical properties of coir fiber reinforced poly(butylen succinate) biodegradable composites. Composites: Part B 42(6): 1648-1656.

Peng, D., Sun, Y.M. \& Yang, L.X. 2011 . Ramie fiber composite material and its application. New Chemical Materials 39(02): 26-28.

Rawal, A. \& Sayeed, M.M.A. 2014. Tailoring the structure and properties of jute blended nonwoven geotextiles via alkali treatment of jute fibers. Materials \& Design 53: 701-705.

Ray, D., Sarkar, B.K. \& Rana, A.K. 2001. Effect of alkali treated jute fibers on composite properties. Bulletin of Materials Science 24(2): 129-135.

Reza, M., Jamaludin, B.M.Y. \& Abdul, R.M.S. 2013. A review of structural performance of oil palm empty fruit bunch fiber 
in polymer composites. Advances in Materials Science and Engineering 4: 1-9.

Reza, M., Jamaludin, M.Y. \& Abdul, R.M.S. 2014. Tensile properties of kenaf fiber due to various conditions of chemical fiber surface modifications. Construction and Building Materials 55(1): 103-113.

Reza, M., Jamaludin, M.Y. \& Abdul, R.M.S. 2014. Characteristics of continuous unidirectional kenaf fiber reinforced epoxy composites. Materials and Design (64): 640-649.

Rokbi, M. 2011. Effect of chemical treatment on flexure properties of natural fiber reinforced polyester composite. Procedia Engineering 10: 2092-2097.

Saha, P., Manna, S. \& Chowdhury, S.R. 2010. Enhancement of tensile strength of lignocellulosic jute fibers by alkali-steam treatment. Bioresour. Technol. 101(9): 3182-3187.

Sathishkumar, T.P., Navaneethankrishnan, P. \& Shankar, S. 2012. Tensile and flexural properties of snake grass natural fiber reinforced isophthallic polyester composites. Composites Science and Technology 72(10): 1183-1190.

Scarponi, C., Schiavoni, E. \& Sanchez-Saez, S. 2012. Polypropylene/hemp fabric reinforced composites: Manufacturing and mechanical behaviour. Journal of Biobased Materials and Bioenergy 6(4): 361-369.

Tim, H., Jörg, M. \& Owen, C. 2012. A critical review of allcellulose composites. Journal of Materials Science 47(3): 1171-1186.

Valadez, G.A. 1999. Effect of fiber surface treatment on the fibermatrix bond strength of natural fiber reinforced composites. Composites Part B 30(3): 309-320.

Wang, C.H.H., Ren, Z.L. \& Zhang, Q.J. 2017. Effect of surface modification of unidirectional bamboo fiber on theproperties of its reinforced unsaturated polyester resin composites. Acta Materiae Compositae Sinica 34(2): 314-321.

Wang, C.H.,Liu, S. \& Ye, Z.H.L. 2016. Mechanical, hygrothermal ageing and moisture absorption properties of bamboo fibers reinforced with polypropylene composites. Journal of Reinforced Plastics and Composites 35(13): 1062-1074.

Wang, C.H.H. \& Liu, S.H.K. 2015. Effect of alkali treatment on properties of bamboo fiber and bamboo fiber reinforced polypropylene composites. Acta Materiae Compositae Sinica 32(3): 683-690.

Wang, L.L., He, L.P. \& Tian, Y. 2008. Effects of surface modification on mechanical properties of sisal fiber reinforced polypropylene composites. Journal of Mechanical Engineering Materials 32(5): 58-61.

Xue, L., Lope, G.T. \& Satyanarayan, P. 2007. Chemical treatments of natural fiber for use in natural fiber-reinforced composites: A review. Journal of Polymers and the Environment 15(01): 25-33.
Zilong Ren, Chunhong Wang* \& Qi Zuo

School of Textile

Tianjin Polytechnic University

300387 Tianjin

China

Zilong Ren, Chunhong Wang* \& Qi Zuo

Key Laboratory of Advanced Textile Composite Materials

Tianjin Polytechnic University

300387 Tianjin

China

Zilong Ren, Chunhong Wang* \& Qi Zuo

Key Laboratory of Hollow Fiber Membrane Material and

Membrane Process of Ministry of Education

Tianjin Polytechnic University

300387 Tianjin

China

Sheraz Hussain Siddique Yousfani

Textile Engineering Department

NED University of Engineering \& Technology

999010 Karachi

Pakistan

Noor Intan Saffinaz Anuar \& Sarani Zakaria

Bioresources and Biorefinery Laboratory

Faculty of Science and Technology

Universiti Kebangsaan Malaysia

43600 UKM Bangi, Selangor Darul Ehsan

Malaysia

Noor Intan Saffinaz Anuar

Fiber and Biocomposite Centre

Malaysian Timber Industry Board

42700 Banting, Selangor Darul Ehsan

Malaysia

Xiaoling Liu

Faculty of Science and Engineering

The University of Nottingham

315100 Ningbo

China

*Corresponding author; email: cn_wangch@163.com

Received: 19 April 2018

Accepted: 12 September 2018 